$\rightarrow \rightarrow$

\title{
Use of Organic Compost for the Fertilization of Piatã and Paiaguás Grasses: Effects of Dose on Morphogenetic, Structural, Nutritional, and Productive Characteristics
}

Marco Antonio Previdelli Orrico Junior, Adriano Pereira da Silveira, Ana Carolina Amorim Orrico, Alice Watte Schwingel, Paulo Lópes Carnavali \& Daniel Chiari Alves

To cite this article: Marco Antonio Previdelli Orrico Junior, Adriano Pereira da Silveira, Ana Carolina Amorim Orrico, Alice Watte Schwingel, Paulo Lópes Carnavali \& Daniel Chiari Alves (2018) Use of Organic Compost for the Fertilization of Piatã and Paiaguás Grasses: Effects of Dose on Morphogenetic, Structural, Nutritional, and Productive Characteristics, Compost Science \& Utilization, 26:3, 201-208, DOI: 10.1080/1065657X.2018.1457998

To link to this article: https://doi.org/10.1080/1065657X.2018.1457998

曲 Published online: 26 Jul 2018.

Submit your article to this journal $\pi$

Ш Article views: 39

View Crossmark data \lceil 


\title{
Use of Organic Compost for the Fertilization of Piatã and Paiaguás Grasses: Effects of Dose on Morphogenetic, Structural, Nutritional, and Productive Characteristics
}

\author{
Marco Antonio Previdelli Orrico Junior ${ }^{\mathrm{a}}$, Adriano Pereira da Silveira ${ }^{\mathrm{a}}$, Ana Carolina Amorim Orrico ${ }^{\mathrm{a}}$, \\ Alice Watte Schwingel ${ }^{b}$, Paulo Lópes Carnavali ${ }^{\mathrm{a}}$, and Daniel Chiari Alves ${ }^{\mathrm{a}}$ \\ ${ }^{\text {a} F e d e r a l ~ U n i v e r s i t y ~ o f ~ G r a n d e ~ D o u r a d o s, ~ C o l l e g e ~ o f ~ A n i m a l ~ S c i e n c e s, ~ D o u r a d o s, ~ M a t o ~ G r o s s o ~ d o ~ S u l, ~ B r a z i l ; ~ b a ̃ o ~ P a u l o ~ S t a t e ~ U n i v e r s i t y, ~ " J u ́ l i o ~ d e ~}$ \\ Mesquita Filho" (UNESP), College of Agricultural Sciences, Fazenda Experimental Lageado, Botucatu, São Paulo, Brazil
}

\begin{abstract}
The use of organic compost in pasture fertilization is a form of recycling nutrients contained in waste and reducing chemical fertilizer use. To perform pasture fertilization, however, grass responses to doses of organic composts must be known. Thus, the objective of this study was to find the best dose of laying hen organic compost to maximize the productive, morphogenetic, structural, and nutritional responses of Paiaguás and Piatã grasses. A completely randomized factorial $(4 \times 2)$ design was used, composed of organic compost doses $\left(0,400,800\right.$, and 1,200 kg equivalent N.ha $\left.{ }^{-1}\right)$ and two cultivars (Piatã and Paiaguás) of Urochloa brizantha grass with three replicates per treatment, assessed during four successive cuts. The parameters evaluated were dry matter yield (DM) of shoots and roots, leaf appearance rate (LAR), leaf elongation rate (LER), phyllochron, pseudoculm elongation rate (PER), final leaf length (FLL), number of green leaves (NGL), and senescence rate (SR). The nutritional value of the grasses was also assessed through contents of dry matter, organic matter, crude protein (CP), neutral detergent fiber (NDF), acid detergent fiber, cellulose, hemicellulose, lignin, and in vitro organic matter digestibility (IVOMD). DM yields of both shoot and root increased due to nitrogen increase and Paiaguás grass had the highest yields $(P<$ 0.01). The best organic compost doses ranged from 640 to $950 \mathrm{~kg}$ of equivalent N.ha ${ }^{-1}$ for most morphogenic and structural grass characteristics. The chemical composition of grasses was not influenced $(P>0.05)$ by doses of organic compost. Levels of $8.05 \% \mathrm{CP}, 67.10 \% \mathrm{NDF}$, and $65.14 \%$ IVOMD were observed for cultivar Paiaguás, while for cultivar Piatã these values were $7.58 \% \mathrm{CP}$, $70.32 \% \mathrm{NDF}$, and $63.38 \%$ IVOMD. It is concluded that high doses of an organic compost are required (in equivalent $\mathrm{N}$ ) for cultivars to reach the highest growth rates and that Paiaguás grass has higher dry matter yield, higher growth rates, and better chemical composition when compared to Piatã grass in similar organic fertilization conditions.
\end{abstract}

\section{Introduction}

Increasing the number of laying hens increases the amount of waste accumulated in aviaries, which may cause serious environmental problems. Therefore, the search for alter native treatment and recycling of such waste is a priority, aiming at both economic and environmental sustainability (Springer, Taliaferro, and Hattey 2005). Organic fertilizer application is beneficial because it increases organic matter content, water retention capacity, and soil aeration, besides reducing the need for mineral fertilizers (Wright et al. 2007).

Animal waste has to undergo treatment to be used as fertilizer and composting is one of the most widely used techniques since, besides ensuring rapid organic matter stabilization, it also reduces the population of pathogens, enabling its safe use in plant fertilization (Franceschini et al. 2016). Not all nutrients present in the organic compost are, however, readily available to plants, and that availability depends on the degree of mineralization Bowden, Spargo, and Evanylo (2007).

Among all the nutrients demanded by forage grasses, nitrogen is required in larger quantities and the analysis of total $\mathrm{N}$ content (organic $\mathrm{N}+$ mineral $\mathrm{N}$ ) is the basis for the calculation of organic compost doses. Nitrogen mineralization depends on the C:N ratio (Eghball and Power 1999) and environmental

CONTACT Marco Antonio Previdelli Orrico Junior marcoorrico@yahoo.com.br College of Animal Sciences, Federal University of Grande Dourados, Dourados, MS, 79.804-970, Brazil.

This article was originally published with errors, which have now been corrected in the online version. Please see Correction (https://doi.org/10.1080 1065657X.2018.1550336).

(c) 2018 Taylor \& Francis 
properties such as soil texture, temperature, and moisture content (Evanylo and Sherony 2002). In general, organic materials with low $\mathrm{C}: \mathrm{N}$ ratio and high nitrogen levels incorporate $\mathrm{N}$ in recalcitrance microbial biomass and humic substances, delaying its release (Sikora and Szmidt 2001). When C:N ratios are greater than 25:1, nitrogen is immobilized in the soil (Flavel et al. 2005).

Bowden, Spargo, and Evanylo (2007), by comparing the availability of $\mathrm{N}$ in five organic composts on the growth of Festuca arundinacea (168 days after application), found values ranging from -0.66 to $49.00 \%$ of $\mathrm{N}$ utilization by plants. According to the data obtained, poultry compost showed the highest $\mathrm{N}$ availability and soil mineralization rates, resulting in greater use by plants. Thus, the authors concluded that high doses of some organic composts are required to achieve the same performance of commercial mineral fertilizers (which feature $\mathrm{N}$ in a more available form to the plant). Thus, plants that have a higher requirement and/or response to nitrogen fertilization require larger amounts of organic composts to meet the $\mathrm{N}$ demand and not have their growth decreased.

Among the various forage grasses species grown in Brazil, Urochloa brizantha is the most widely used, mainly in the North and Center-West regions of the country. Its success is due to productivity, weather tolerance, and good adaptation to different soil types in Brazil (Meirelles et al. 2011; Pariz et al. 2017). These factors contributed to several Urochloa brizantha cultivars being launched on the market, of which Piatã and Paiaguás are the most recent. According to preliminary data, these cultivars respond well to mineral nitrogen fertilization (Nakamura et al. 2005), however, there are few studies that compare these two cultivars, especially considering growth rates, dry matter yield, and nutritional value. Euclides et al. (2016) reported Paiaguás grass results in higher beef cattle weight gain compared to Piatã grass. This superior animal performance indicates Paiaguás grass has higher dry matter yield and/or better nutritional value compared to Piatã grass.

Thus, knowledge of the response of these cultivars to different doses of organic compost is of utmost importance to establish fertilization to promote further plant development (Springer, Taliaferro, and Hattey 2005), in addition to encouraging the use of organic composts in grazing areas.

Therefore, the objectives of the study were: 1) To find the best dose of organic compost to maximize productive, morphogenetic, and structural responses of
Piatã and Paiaguás grasses and 2) To evaluate which cultivar has better response to organic fertilizers. The first study hypothesis is that, due to the low availability of $\mathrm{N}$ in the organic compost, high doses are required to achieve maximum plant growth. The second hypothesis is that with higher $\mathrm{N}$ doses, the Paiaguás cultivar performs better than Piatã, as suggested by the literature.

\section{Material and Methods}

The research was conducted at the School of Agricultural Sciences of the Universidade Federal da Grande Dourados - UFGD (latitude $22^{\circ} 11^{\prime} 55^{\prime \prime} \mathrm{S}$, longitude $54^{\circ} 56^{\prime} 7^{\prime \prime} \mathrm{W}$, and $452 \mathrm{~m}$ altitude) in the municipality of Dourados, MS, Brazil. The experiment was conducted in a simple arch-type greenhouse with East-West orientation with sides closed with shade cloth and covered with clear plastic canvas.

The trial employed a completely randomized factorial split-plot in time design. The plots comprised eight treatments: Four doses of organic compost $(0,400,800$, and $1,200 \mathrm{~kg}$ equivalent N.ha ${ }^{-1}$ ) and two cultivars of Urochloa brizantha (Piatã and Paiaguás) grass, while the split-plots were the four cutting periods. Each treatment had three replicates (pot volume $4 \mathrm{dm}^{3}$ ).

The organic compost used was the composting product of laying hen waste (feces, urine, eggshells, and food scraps). During composting, moisture, temperature, and aeration were monitored, allowing for quick and efficient stabilization of organic material. After 70 days from the beginning of the process, the compost was considered stable for having constant C: $\mathrm{N}$ ratio (nearly 10:1). The chemical composition of the organic compost was $3.3,4.0,5.4,12.0,0.5$, and $2.1 \%$ of $\mathrm{N}, \mathrm{P}, \mathrm{K}, \mathrm{Ca}, \mathrm{Mg}$, and $\mathrm{S}$, respectively. Organic compost doses were calculated considering pot volume and compost $\mathrm{N}$ content (Kjeldahl-N) (table 1).

The soil was classified as a dystrophic Red Latosol (Oxisol) with clayey texture and had the following characteristics: $\mathrm{pH}$ in $\mathrm{CaCl}_{2}$ : 4.50; $\mathrm{P}, 2.17$ g. $\mathrm{dm}^{-3}$; K,

Table 1. Organic compound doses and their conversion into equivalent $\mathrm{N}$ per hectare and per pot.

\begin{tabular}{|c|c|c|c|c|}
\hline Doses & $\begin{array}{c}0 \mathrm{~kg} \mathrm{~N} . \\
\mathrm{ha}^{-1}\end{array}$ & $\begin{array}{c}400 \mathrm{~N} . \\
\mathrm{ha}^{-1}\end{array}$ & $\begin{array}{c}800 \mathrm{~N} . \\
\mathrm{ha}^{-1}\end{array}$ & $\begin{array}{c}1200 \mathrm{~N} \\
\mathrm{ha}^{-1}\end{array}$ \\
\hline $\mathrm{kg}$ of equivalent N.ha- $1^{*}$ & 0.00 & 400 & 800 & 1200 \\
\hline kg of organic compound.ha ${ }^{-1}$ & 0.00 & 12.120 & 24.240 & 36.360 \\
\hline $\mathrm{g}$ of organic compound.pot ${ }^{-1 * *}$ & 0.00 & 24.24 & 48.48 & 72.72 \\
\hline $\mathrm{g}$ of equivalent N.pot ${ }^{-1}$ & 0.00 & 0.80 & 1.60 & 2.40 \\
\hline
\end{tabular}


$0.09 \mathrm{cmol}_{\mathrm{c}} \cdot \mathrm{dm}^{-3} ; \mathrm{Ca}^{+2}, 0.31 \mathrm{cmol}_{\mathrm{c}} \cdot \mathrm{dm}^{-3} ; \mathrm{Mg}^{+2}, 0.07$ $\mathrm{cmol}_{c} \cdot \mathrm{dm}^{-3} ; \mathrm{Al}^{+3}, 50.53 \mathrm{cmol}_{\mathrm{c}} \cdot \mathrm{dm}^{-3} ; \mathrm{H}^{+} \mathrm{Al}, 4.96$ $\mathrm{cmol}_{\mathrm{c}} \cdot \mathrm{dm}^{3}$; CEC, $5.43 \mathrm{cmol}_{\mathrm{c}} \cdot \mathrm{dm}^{3}$; and BS, $8.66 \%$. Liming with ECCE $86 \%$ limestone was performed to correct soil acidity and a dose of $5.7 \mathrm{~g} \mathrm{pot}^{-1}$ was used to raise base saturation to 50\%. After 60 days of liming completion, Paiaguás and Piatã grasses were sowed using 10 seeds per pot. Pot moisture was monitored every three days by weighing them to maintain the soil at $70 \%$ field capacity. Irrigation was done with distilled water in order to avoid the interference of the nutrients present in regular water.

In the period of grass formation, the three best plants in each pot were selected based on the plants that showed better development and the rest was discarded. Before the first data collection cycle, a cut was made (45 days after planting) for forage grass uniformity at $15 \mathrm{~cm}$ from the ground (grazing height recommended for this species).

After the forage grass uniformity cut, three tillers were marked with colored threads and beads per grass pot, totaling 144 tillers. Measurements were performed every three days with a ruler graduated in $\mathrm{cm}$ and data were recorded on the appearance of the leaf apex, day of ligule exposure, pseudoculm length, leaf blades expanded and under expansion, number of leaves per tiller, and number of live, dead, and senescent leaves. Four cuts were performed at 28-day intervals and fertilization was carried out in portions. After each cut, doses of $0,100,200$, and $300 \mathrm{~kg} \mathrm{~N} . \mathrm{ha}^{-1}$ were administered, totaling doses of $0,400,800$, and $1,200 \mathrm{~kg} \mathrm{~N} . \mathrm{ha}^{-1}$ at the end of the trial period.

Data were used to calculate the following variables: 1) Leaf appearance rate (LAR, leaves.tillers.day ${ }^{-1}$ ), which is estimated by dividing the total tiller leaf number by the regrowth period, expressed in leaves.day ${ }^{-1}$; 2) Phyllochron $\left(\right.$ day $\left.^{-1}\right)$, determined by the inverse of leaf appearance rate.day ${ }^{-1}$; 3) Leaf elongation rate (LER, cm. day $^{-1}$ ), calculated as the difference between the initial and final lengths of emerging leaves divided by the number of days between measurements; 4) Pseudoculm elongation rate (PER, $\mathrm{cm}^{-\mathrm{day}^{-1}}{ }^{-}$, calculated as the difference between initial and final height (calculated based on the ground level to the ligule of the last expanded leaf of each tiller) divided by the number of days involved; 5) Final leaf length (FLL, $\mathrm{cm}$ ), which stands for the fully expanded leaves measured from ligule insertion up to the leaf apex. Only the leaves with fully exposed ligule of the assessed tillers were measured; 6) Number of green leaves (NGL, green.leaves.tiller ${ }^{-1}$ ), determined by counting the number of green leaves in expansion and expanded in marked tillers; and 7) Senescence rate (SR, $\mathrm{cm} \cdot \mathrm{day}^{-1}$ ), estimated considering the time between the appearance of the leaf apex and the first sign of blade senescence (Lemaire and Chapman 1996).

Total shoot dry matter (DM) yield (forage harvested above $15 \mathrm{~cm}$ from the ground) was the sum of the four cuts. Root DM yield was determined by the DM mass of roots in the pot after the last cut. Sample DM content (shoots and roots) was held in a forcedair oven at $65^{\circ} \mathrm{C}$ per minute for at least $72 \mathrm{~h}$ according to the methodology described by Silva and Queiroz (2002).

After drying, forage samples were finely ground (Wiley mill with $1 \mathrm{~mm}$ sieve) and used for the determination of crude protein (CP), neutral detergent fiber (NDF), acid detergent fiber (ADF), lignin, cellulose, hemicellulose, and in vitro organic matter digestibility (IVOMD) in near-infrared spectrophotometry (NIRS) (Marten, Shenk, and Barton 1985).

Results were submitted to analysis of variance considering the dose of organic fertilizer, cultivar, cuts, and their interaction as sources of variation tested at $1 \%$ probability. The effect of equivalent nitrogen dose was evaluated by regression analysis and cultivars and cuts were compared by $\mathrm{F}$ test (1\%). The cuts did not significantly differ according to $\mathrm{F}$ test, thus they are not presented in the text. Analyses were performed using the software R (version 3.1.0 for Windows).

\section{Results and Discussion}

DM yields of both shoots and roots increased due to nitrogen increase $(P<0.01)$, following a quadratic behavior prediction (figure 1). Many studies in the literature demonstrate the positive correlation between nitrogen fertilization and dry matter yield of tropical grasses (Cabral et al. 2012; Costa et al. 2013). This behavior is because nitrogen promotes a significant increase in enzymatic reactions and plant metabolism, providing higher leaf chlorophyll content, thus increasing the supply of photo-assimilates that directly influence biomass yield (Vitor et al. 2009).

In the specific case of this study, the highest dose tested, $1,200 \mathrm{~kg}$ equivalent N.ha ${ }^{-1}$, was not enough to reach the maximum yield of the forage grasses (shoots and roots) for either cultivar. Such doses may be considered high when compared to those present in 

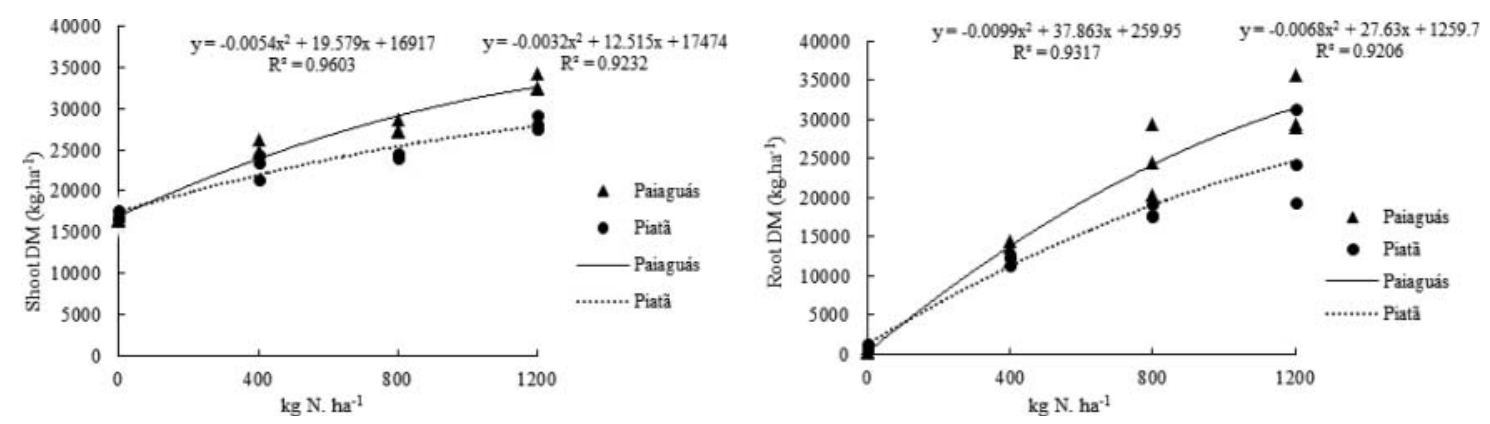

Figure 1. Total dry matter yield of shoots and roots (g.pot ${ }^{-1}$ ) of Piatã and Paiaguás grasses, depending on the organic compound doses equivalent $\mathrm{kg} \mathrm{N} \cdot \mathrm{ha}^{-1}$.

the literature, which generally find the point of maximum DM yield between 240 and $887 \mathrm{~kg}$ N.ha ${ }^{-1}$ (Santini et al. 2016; Primavesi et al. 2004). This is probably because those authors used mineral fertilizers in their research, which showed $\mathrm{N}$ readily available to plants, unlike organic fertilization, which provides $\mathrm{N}$ gradually, according to the degree of organic material mineralization (Gutser et al. 2005). According to those authors, many organic fertilizers have little effect on crop growth in the year of application, ranging from $0 \%$ (some composts with high C:N ratio) to almost $100 \%$ (urine).

Orrico Junior et al. (2013a), when working with biofertilizers originated from poultry slaughterhouse wastewater in the fertilization of Piatã grass, found DM.cut ${ }^{-1}$ yields similar to those obtained in this study (same soil conditions, time of year, and pot management). However, the authors in that work needed only $250 \mathrm{~kg}$ equivalent $\mathrm{N} \cdot \mathrm{ha}^{-1}$ for the same DM yield observed, compared to fertilization with $1,200 \mathrm{~kg}$ equivalent N.ha ${ }^{-1}$ of organic compost in this study. The reason for this difference is the type of treatment to which the waste had been previously submitted. Anaerobic biodigestion increases $\mathrm{NH}_{4}{ }^{+}-\mathrm{N}$ concentration in the environment, increasing mineral $\mathrm{N}$ content, while composting reduces the proportion of $\mathrm{NH}_{4}{ }^{+}-\mathrm{N}$ and, consequently, the amount of mineral $\mathrm{N}$ (Gutser et al. 2005). Thus, the authors concluded that, in the short term, organic bio-composts require higher application rates to achieve the same performance of other types of organic fertilizers.

Piatã and Paiaguás cultivars show different DM yields because of fertilization. The data presented in table 2 demonstrate that Paiaguás grass obtained higher $(P<0.01)$ DM yield (shoots and roots) compared to Piatã grass.

Based on shoot DM yield (table 2), yields of 25,640.00 kg DM.ha ${ }^{-1}$ can be seen for Paiaguás grass and of $23,200.00 \mathrm{~kg} \mathrm{DM} / \mathrm{ha}^{-1}$ for Piatã grass, i.e., a superiority of $10.51 \%$ for the former. When the same comparison is made at the highest equivalent nitrogen dose $\left(1,200 \mathrm{~kg} \mathrm{~N} \cdot \mathrm{ha}^{-1}\right)$, this difference increased to $22.78 \%$. Root system development is essential for the plant to assimilate soil nutrients, so plants with welldeveloped root systems have higher growth potential. In the comparison of grasses, Paiaguás showed root DM yield (table 2) of 34.23 g pot $^{-1}$, or $22.11 \%$ greater than that of Piatã grass. A different outcome was obtained by Port et al. (2014) when comparing the root yield of three cultivars of Urochloa brizantha (Marandu, Piatã, and Xaraés), with different nitrogen doses $\left(0,80,160\right.$, and $\left.240 \mathrm{~kg} \mathrm{~N} . \mathrm{ha}^{-1}\right)$. Those authors only observed the effect of nitrogen rates on root yield (85.99\% increase), with no difference $(P>0.05)$ among cultivars. Thus, they concluded that the three cultivars of Urochloa brizantha showed similarities with respect to root yield, unlike what was observed in this study for Paiaguás grass.

Quadratic prediction models were obtained for the morphogenetic and structural characteristics, making

Table 2. Average values of productive, morphogenetic, and structural characteristics of Urochloa brizantha cv. Piatã and Paiaguás.

\begin{tabular}{|c|c|c|c|c|}
\hline Parameters & Paiaguás & Piatã & $P$ & CV\% \\
\hline DM yield $\left(\mathrm{kg}_{\mathrm{ha}}{ }^{-1}\right)$ & $25,640.00$ & $23,200.00$ & $<0.01$ & 3.61 \\
\hline Root DM yield $\left(\mathrm{kg} \mathrm{ha}^{-1}\right)$ & $17,115.00$ & $14,015.00$ & $<0.01$ & 12.3 \\
\hline Phyllochron (days) & 11.28 & 14.45 & $<0.01$ & 8.97 \\
\hline LAR (leaf.day ${ }^{-1}$ ) & 0.10 & 0.07 & $<0.01$ & 7.67 \\
\hline PER $\left(\mathrm{cm} \cdot \mathrm{day}^{-1}\right)$ & 0.21 & 0.12 & $<0.01$ & 11.01 \\
\hline LER (cm.day ${ }^{-1}$ ) & 1.99 & 1.60 & $<0.01$ & 13.73 \\
\hline SR $\left(\mathrm{cm} \cdot \mathrm{day}^{-1}\right)$ & 0.38 & 0.19 & $<0.01$ & 45.18 \\
\hline FLL $(\mathrm{cm})$ & 20.34 & 18.94 & $<0.01$ & 6.47 \\
\hline NGL (live leaves ${ }^{-1}$ tiller $^{-1}$ ) & 4.63 & 4.65 & 0.07 & 7.58 \\
\hline
\end{tabular}

$\mathrm{DM}=$ dry matter; $\mathrm{LAR}=$ leaf appearance rate; $\mathrm{PER}=$ stem elongation rate; $\mathrm{LER}=$ leaf elongation rate; $\mathrm{SR}=$ senescence rate; $\mathrm{FL}=$ final leaf length; $\mathrm{NGL}=$ number of green leaves; $\mathrm{CV} \%=$ coefficient of variation and $\mathrm{P}=\mathrm{P}$ value. 
it possible to identify the maximum points as a function of organic fertilizer doses (figure 2).

The lowest phyllochron (8.4 days) was found at a dose of $832 \mathrm{~kg}^{-1}$ equivalent N.ha ${ }^{-1}$ for Paiaguás grass. As for Piatã grass, the lowest phyllochron was obtained for the dose of $652 \mathrm{~kg} \mathrm{~N} . \mathrm{ha}^{-1}$, corresponding to 13.3 days. When comparing the average phyllochron (table 2) of Paiaguás and Piatã grasses, average values of 11.28 and 14.45 days are found, respectively, which is equivalent to a reduction by 3.17 days in the interval between two successive leaves. According to Orrico Junior et al. (2013b), the lower phyllochron value enables the plant to reach a maximum number of green leaves per tiller within a shorter time, thus anticipating the cut (larger number of cuts) and preventing a large number of senescent leaves per tiller.

The PER is a characteristic influenced by the length of each leaf elongation, i.e., the greater the length of the lower phyllochron, the lower the PER. This behavior can be observed for the cultivars in question, with
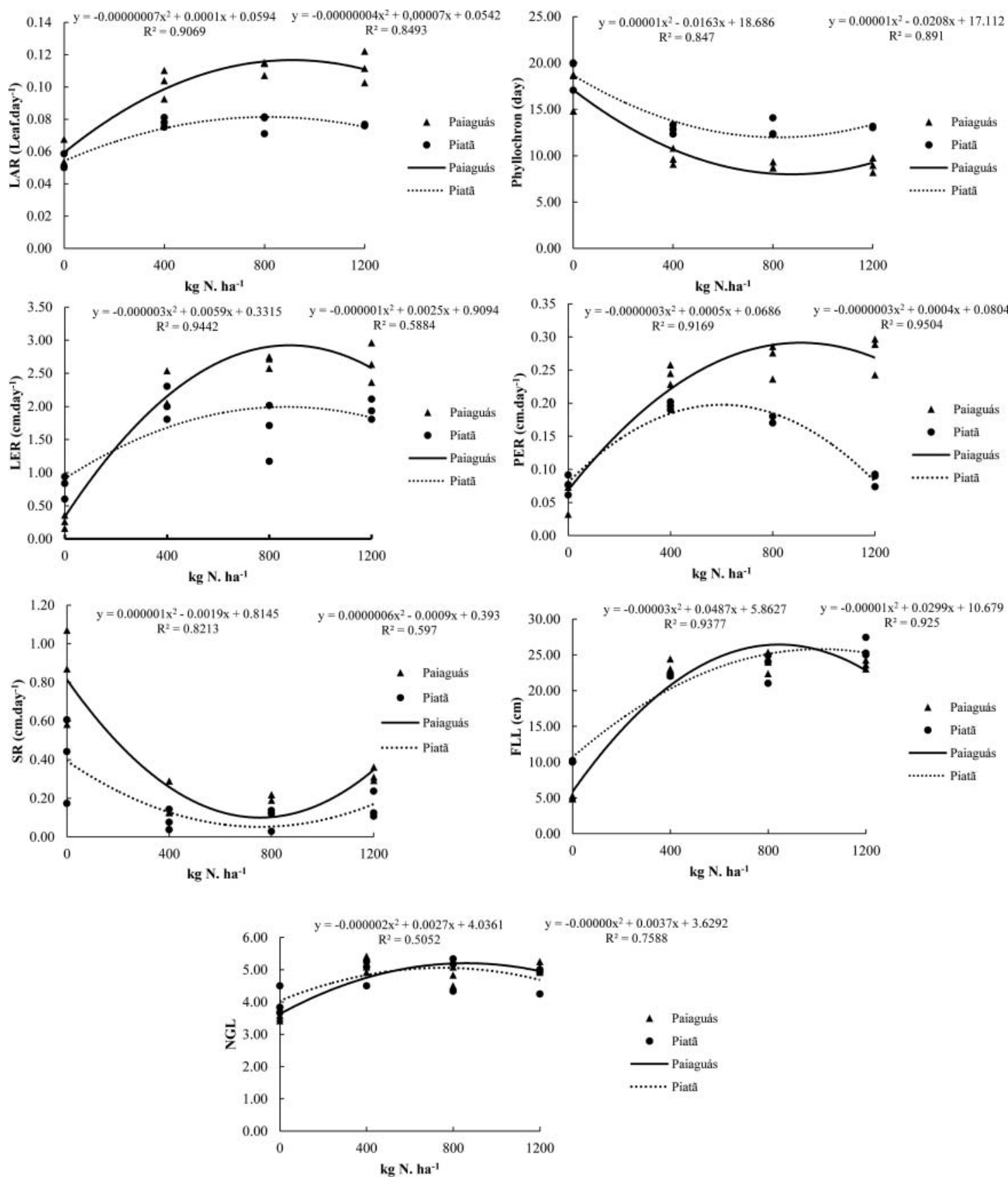

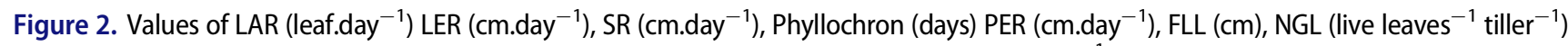
of Piatã and Paiaguás grasses in function of the organic compound doses in equivalent $\mathrm{kg} \mathrm{N} \mathrm{ha}{ }^{-1}$. 
Piatã grass having the lowest PER values (table 2) and, consequently, greater phyllochron. The LER was influenced by $\mathrm{N}$ rates and the type of grass tested. The highest value of LER was $3.24 \mathrm{~cm}^{-d_{a y}}{ }^{-1}$ for Paiaguás grass at the rate of $983.33 \mathrm{~kg} \mathrm{~N} . \mathrm{ha}^{-1}$, whereas for Piatã grass, the greatest LER was $2.30 \mathrm{~cm}$. day ${ }^{-1}$ for a dose of $856 \mathrm{~kg} \mathrm{~N} \cdot \mathrm{ha}^{-1}$. The highest leaf growth rates were sufficient to significantly increase $(P<0.01)$ Paiaguás grass FLL, despite the shorter leaf elongation time (phyllochron). The average FLL values for Paiaguás and Piatã grasss were $20.34 \mathrm{~cm}$, and $18.94 \mathrm{~cm}$, respectively.

Piatã grass showed lower SR (table 2) when compared to Paiaguás. Average SR of $0.19 \mathrm{~cm}^{-d_{a y}}{ }^{-1}$ was observed for Piatã grass, whereas the mean SR for Paiaguás grass was $0.38 \mathrm{~cm} \cdot$ day $^{-1}$. Senescence of both kinds of grass increased due to the higher $\mathrm{N}$ dose. According to Silva et al. (2009), in the absence of fertilization, plants remained with their green leaves longer at the expense of slower growth of new leaves, i.e., the senescence process of these forages is accelerated with increased nitrogen rates. This also explains the fact that the SR of Paiaguás grass was greater than that of Piatã grass because the accelerated growth of Paiaguás grass contributed to faster leaf aging.

There were no differences $(P>0.05)$ in NGL among grasses, despite the higher senescence rate of cultivar Paiaguás. Thus, both Piatã and Paiaguás have the same ability to keep the number of live leaves per tiller, an important feature since the leaf is the favorite fraction to be ingested by grazing animals. $\mathrm{N}$ doses influenced the NGL $(P<0.01)$, with values of 4.95 live leaves ${ }^{-1}$ tiller $^{-1}$ (dose of $675 \mathrm{~kg} \mathrm{~N}^{-h a^{-1}}{ }^{\text {), and } 5.34}$ live leaves ${ }^{-1}$ tiller $^{-1}$ (for the dose of $925 \mathrm{~kg} \mathrm{~N} \mathrm{ha}^{-1}$ ) for Paiaguás and Piatã grasses, respectively. Cabral et al. (2012) observed a positive linear response between NGL values and nitrogen levels for Xaraés grass using urea as nitrogen fertilizer.

Grass chemical compositions were not influenced $(P>0.05)$ by the doses of organic compost, in contrast with Orrico Junior et al. (2014), who evaluated the chemical composition of Piatã grass in a greenhouse under increasing doses of organic fertilization $\left(100,200\right.$, and $300 \mathrm{~kg}$ equivalent N.ha $\left.{ }^{-1}\right)$. Those authors found that organic fertilizer doses (in equivalent $\mathrm{N}$ ) positively influenced plant nutritional value, increasing the dry matter, crude protein, and in vitro digestibility, with consequent reduction of fiber constituents. Orrico Junior et al. (2014), however, used height as plant cutting criteria, so the plants that received the highest $\mathrm{N}$ doses were harvested within a short time, which eventually favored the harvest of more nutritious plants.

When the cultivars were compared, differences were observed $(P<0.01)$ in most nutritional parameters. Levels of $8.05 \%$ were observed in CP, $67.10 \%$ NDF, and 65.14\% IVOMD for cultivar Paiaguás, while for Piatã these values were $7.58 \%$ for $\mathrm{CP}, 70.32 \%$ NFD, and 63.38\% IVOMD (table 3).

The probable reason for this better nutritional quality is the fact that cultivar Paiaguás had a higher proportion of leaves (due to higher LAR, LER, and FLL), the most nutritious part of the plant (Van Soest 1994). The superiority of Paiaguás grass in both qualitative and quantitative terms contribute with the results of Euclides et al. (2016), who found higher weight gain of cattle on Paiaguás grass pasture $\left(695 \mathrm{~kg} \mathrm{ha}^{-1}\right.$ per year) compared to Piatã grass pasture $\left(645 \mathrm{~kg} \mathrm{ha}^{-1}\right.$ per year).

The results obtained in this study show that organic fertilization could be an interesting alternative to reduce the use of mineral fertilizers in pastures without causing problems in grass yield. However, high doses of these organic composts are necessary to maximize yield due to the slow release of nutrients to plants. This factor can be viewed as an advantage of the use of organic composts because the slow release guarantees (especially in the case of $\mathrm{N}$ ) fewer losses by leaching in case plants require fewer soil nutrients. Cultivar Paiaguás proved to be a potentially interesting grass for livestock yield in Brazil, although further research (different soils, climates, pest management) is required so this cultivar can be recommended.

Table 3. Average values of organic matter $(O M)$, crude protein $(C P)$, neutral and acid detergent fiber (NDF and ADF), lignin, cellulose, hemicellulose and "in vitro" organic matter digestibility (IVOMD) of species Urochloa brizantha cv. Piatã and Paiaguás.

\begin{tabular}{lrrrl}
\hline Parameters & Paiaguás & Piatã & \multicolumn{1}{c}{$P$} & CV\% \\
\hline OM (\% MS) & 93.80 & 94.02 & 0.45 & 12.21 \\
CP (\%MS) & 8.05 & 7.58 & $<0.01$ & 11.2 \\
NDF (\%MS) & 67.10 & 70.32 & $<0.01$ & 13.4 \\
ADF (\%MS) & 31.06 & 31.26 & 0.34 & 12.23 \\
IVOMD (\%) & 65.14 & 63.38 & $<0.01$ & 15.67 \\
Lignin (\%MS) & 4.90 & 5.30 & $<0.01$ & 10.34 \\
Cellulose (\%MS) & 25.43 & 25.45 & 0.69 & 11.36 \\
Hemicellulose (\%MS) & 36.80 & 39.06 & $<0.01$ & 12.37 \\
\hline
\end{tabular}

$\mathrm{CV} \%=$ coefficient of variation and $\mathrm{P}=\mathrm{P}$ value. 


\section{Conclusion}

The data presented support the first hypothesis of this study because very high doses of organic compost were required (in equivalent $\mathrm{N}$ ) for the cultivars to reach the highest growth rates. Organic compost doses ranged from 640 to $950 \mathrm{~kg}$ of equivalent N.ha ${ }^{-1}$ for most morphogenetic and structural characteristics of grasses and DM yields (shoots and roots) were higher at the dose of $1,200 \mathrm{~kg}$ of equivalent N.ha ${ }^{-1}$.

The second hypothesis was also confirmed, i.e., Paiaguás grass showed higher dry matter yield, higher growth rates, and better chemical composition when compared to Piatã grass in similar organic fertilization conditions.

\section{Acknowledgments}

This research was carried out with the financial support of the Federal University of Greater Dourados (UFGD) and of the Foundation for the Support of the Development of Teaching, Science and Technology of the state of Mato Grosso do Sul (Fundect), besides the master's degree scholarship provided by the Coordination for the Improvement of Higher Education Personnel (CAPES).

\section{Funding}

This research was carried out with the financial support of the Federal University of Grande Dourados (UFGD) and of the Foundation for the Support to the Development of Teaching, Science and Technology of the state of Mato Grosso do Sul (Fundect-0239/2014), besides the Master's degree scholarship provided by the Coordination for the Improvement of Higher Level Personnel (CAPES).

\section{References}

Bowden, C., J. Spargo, and G. Evanylo. 2007. Mineralization and $\mathrm{N}$ Fertilizer Equivalent Value of Composts as Assessed by Tall Fescue (Festuca arundinacea). Compost Science \& Utilization 15(2):111-18. doi:10.1080/1065657X.2007.10702320.

Cabral, W. B., A. L. Souza, E. Alexandrino, F. L. B. Toral, J. N. Santos, and M. V. P. Carvalho. 2012. Características Estruturais e Agronômicas da Brachiaria Brizantha cv. Xaraés Submetida a Doses de Nitrogênio. Revista Brasileira de Zootecnia 41 (4):846-55. doi:10.1590/S1516-35982012000400004.

Costa, N. L., A. Moraes, P. C. F Carvalho, A. L. G. Monteiro, and R. A. Oliveira. 2013. Características Morfogênicas e Estruturais de Trachypogon Plumosus de Acordo com a Fertilidade do Solo e o Nível de Desfolha. Pesquisa Agropecuária Brasileira 48(3):320-28. doi:10.1590/S0100-204X2013000300011.

Eghball, B. and J. F. Power. 1999. Composted and non-composted manure application to conventional and no-tillage systems: Corn yield and nitrogen uptake. Agronomy Journal 91:819-25. doi:10.2134/agronj1999.915819x.

Euclides, V. P. B., D. B. Montagner, R. A. Barbosa, C. B. Valle, and N. N. Nantes. 2016. Animal performance and sward characteristics of two cultivars of Brachiaria brizantha (BRS Paiaguás and BRS Piatã). Revista Brasileira de Zootecnia 45(3):85-92. doi:10.1590/S1806-92902016000300001.

Evanylo, G. K. and C. A. Sherony. 2002. Agronomic and environmental effects of compost, manure, and fertilizer use. In: International symposium: Composting and compost utilization, ed. F. C. Michel, Jr., R. F. Rynk, and H. A. J., Hoitink. pp. 730-40. Emmaus, PA: JG Press Inc.

Flavel, T.C., D.V. Murphy, B.M. Lalor, and I.R.P. Fillery. 2005. Gross nitrogen mineralization rates after application of composted grape Marc to soil. Soil Biology and Biochemistry 37:1397-400. doi:10.1016/j.soilbio.2004.12.003.

Franceschini, S., W. Chitarra, M. Pugliese, U. Gisi, A. Garibaldi, and M. G. Lodovica. 2016. Quantification of Aspergillus fumigatus and enteric bacteria. European Compost and Biochar. 24(1):20-29.

Gutser, R., T. Ebertseder, A. Weber, M. Schraml, and U. Schmidhalter. 2005. Short-Term and residual availability of nitrogen after long-term application of organic fertilizers on Arable land. Journal of Plant Nutrition and Soil Science 168:439-46. doi:10.1002/jpln.200520510.

Lemaire, G. and D. Chapman. 1996. Tissue flows in grazed plant communities. In: The Ecology and Management of Grazing Systems, ed. J. Hodgson and A. W. Illius. pp. 03-36: Cab international.

Marten, G. C., J. S. Shenk, and F. E. Barton, II. 1985. Near infrared reflectance spectroscopy (NIRS): analysis of forage quality. Agriculture Handbook, U.S. Department of Agriculture, Washington, USA.

Meirelles, M. L., A. C. Franco, S. E. M. Farias, and R. Bracho. 2011. Evapotranspiration and Plant-atmospheric coupling in a Brachiaria brizantha Pasture in the Brazilian Savannah Region. Grass and Forage Science 66:206-13. doi:10.1111/ j.1365-2494.2010.00777.x.

Nakamura, T., C. H. B. Miranda, Y. Ohwaki, J. C. R. ValCio, Y. Kim, and M. C. M. Macedo. 2005. Characterization of nitrogen utilization by Brachiaria grasses in Brazilian Savannas (Cerrados). Soil Science and Plant Nutrition 61 (7):973-79. doi:10.1111/j.1747-0765.2005.tb00136.x.

Orrico, M. A. P., Jr, A. C. A. Orrico, S. R. Centurion, N.S. Sunada, and F.M. Vargas. 2013b. Características Morfogênicas do Capim-piatã Submetido à Adubação com Efluentes de Abatedouro Avícola. Ciência Rural 43:158-63. doi:10.1590/S0103-84782012005000125.

Orrico, M. A. P., Jr, A. C. A. Orrico, S. R. Centurion, N. S. Sunada. 2014. Potencial Bromatológico do Capim Piatã Cultivado em Sistema Orgânico. Revista Agrarian 7(5): 447-53.

Orrico, M. A. P., Jr, S. R. Centurion, A. C. A. Orrico, A. B. M Oliveira, and N. S. Sunada. 2013a. Características Produtivas, Morfogênicas e Estruturais do Capim Piatã Submetido à Adubação Orgânica. Ciência Rural 43:1238-44. doi:10.1590/S0103-84782013005000085 
Pariz, C. M., C. Costa, C. A. C. Crusciol, P. R. L. Meirelles, A. M. Castilhos, M. Andreotti, N. R. Costa, et al. 2017. Production, nutrient cycling and soil compaction to grazing of grass companion cropping with corn and soybean. Nutrient Cycling in Agroecosystems 108:35-54. doi:10.1007/s10705-016-9821-y.

Porto, E. M. V., C. M. T. Vitor, D. D. Alves, D. R. Oliveira, M. R. Doroteu, and V. D. Gonçalves. 2014. Densidade Populacional de Perfilhos de Cultivares de Brachiaria Brizantha Submetidos à Adubação Nitrogenada. Agropecuária Científica no Semiárido 10(4):46-51.

Primavesi, A. C., O. Primavesi, L. A Corrêia, H. Cantarella, and A. G. Silva, 2004. Extração de Nutriente e Recuperação Aparente do Nitrogênio pelo Capim Coastcross Adubado. Revista Ceres 51(295):295-306.

Santini, J. M. K., A. Perin, D. N. Coaguila, M. Valderrama, E. Dupas, C. G. Santos, V. M. Silva, and S. Buzetti. 2016. Adubação Nitrogenada na Implantação de Urochloa brizantha cv. xaraés no Cerrado: Características Biométricas e Bromatológica. Brazilian Journal of Biosystems Engineering 10(2):129-39.

Sikora, L. J. and R. A. K. Szmidt. 2001. "Nitrogen sources, mineralization rates, and nitrogen nutrition benefits to plants from composts. In: Compost utilization in horticultural cropping systems, ed. P. Stoffella and B. A. Kahn. pp. 287-320. Boca Raton, FL: Lewis Publishers.
Silva, C. C. F., B. Bonomo, A. J. V. Pires, C. M. A. Maranhão, N. M. S. Patês, and L. C. Santos. 2009. Características Morfogênicas e Estruturais de Duas Espécies de Braquiária Adubadas com Diferentes Doses de Nitrogênio. Revista Brasileira de Zootecnia 38(4):657-61. doi:10.1590/S151635982009000400010.

Silva, D. J. and A. C. Queiroz. 2002. Análise de alimentos (métodos químicos e biológicos). Viçosa MG: Editora UFV. pp. 235.

Springer, T. L., C. M. Taliaferro, and J. A. Hattey. 2005. Nitrogen source and rate effects on the yield of buffalograss forage grown with irrigation. Crop Sci. 45:668-72. doi:10.2135/ cropsci2005.0668.

Van Soest, P. J. 1994. Nutritional ecology of the ruminant. Ithaca, NY: Cornell University. Press. pp. 476.

Vitor, C. M. T., D. M. Fonseca, A. C. Cóser, C. E. Martins, D. Nascimento, Jr, and J. I Ribeiro, Jr. 2009. Produção de Matéria Seca e Valor Nutritivo de Pastagem de Capim-elefante sob Irrigação e Adubação Nitrogenada. Revista Brasileira Zootecnia 38(3):435-42. doi:10.1590/ S1516-35982009000300006.

Wright, A. L., T. L. Proving, F. M. Hons, D. A. Zuberer, and R. H. White. 2007. Compost source and rate effects on soil macronutrient availability under saint Augustine Grass and Bermuda Grass Turf. Compost Science \& Utilization 15 (1):22-28. doi:10.1080/1065657X.2007.10702306. 